\title{
JURNAL LESTELATAN ITEGUUGAN

\section{GAMBARAN TINGKAT KEBISINGAN DAN KELUHAN SUBJEKTIF DARI AKTIVITAS TRANSPORTASI DI KAWASAN PERDAGANGAN DAN PERKANTORAN KOTA KENDARI}

\section{An Overview of Noise Levels and Subjective Complaints from Transportation Activities in Kendari City Commercial and Office Areas}

\section{Fatma',Ramadhan Tosepu ${ }^{2}$,Fifi Nirmala $G^{3}$}

Jurusan Kesehatan Masyarakat, Fakultas Kesehatan Masyarakat, Universitas Halu Oleo (fatmaima927@gmail.com¹, ramadhan.tosepu@uho.ac.id², fifinirmala87@gmail.com³)

\begin{tabular}{l}
\hline INFO ARTIKEL \\
\hline Diterima: \\
Juli 2020 \\
Dipublikasi: \\
Oktober 2020 \\
\hline
\end{tabular}

Kata kunci:

Kebisingan, volume lalu lintas, keluhan subjektif

\section{Keywords:}

Noise, traffic volume, subjective complaints

*PenulisKorespondensi Alamat email: ramadhan.tosepu@uho. ac.id (Ramadhan Tosepu)

\begin{abstract}
Abstrak
Kebisingan adalah bunyi yang tidak diinginkan dari usaha atau kegiatan dalam tingkat dan waktu tertentu yang dapat menimbulkan gangguan kesehatan manusia dan kenyamanan lingkungan. Penggunaan kendaraan bermotor yang tinggi meningkatkan masalah lingkungan seperti polusi udara dan kebisingan lalu lintas. Tujuan penelitian ini ialah untuk mengetahui gambaran tingkat kebisingan dan keluhan subjektif dari aktivitas transportasi di kawasan perdagangan dan perkantoran Kota Kendari. Metode penelitian yang digunakan adalah deskriptif. Hasil penelitian menunjukkan bahwa tingkat kebisingan di Jalan MT. Haryono telah melebihi baku mutu yang ditetapkan yaitu $65 \mathrm{~dB}(\mathrm{~A})$, di Jalan $\mathrm{H}$. Abdullah Silondae belum melebihi baku mutu yang ditetapkan yaitu $65 \mathrm{~dB}(\mathrm{~A})$ dan di jalan Katambak, Kota Lama telah melebihi baku mutu yang ditetapkan yaitu $65 \mathrm{~dB}(\mathrm{~A})$. Volume lalu lintas di jalan MT. Haryono tertinggi yaitu pukul 15.00 WITA sebanyak 1.121 unit, di jalan H. Abdullah Silondae volume kendaraan tertinggi yaitu pukul 15.00 WITA sebanyak 473 unit, dan di jalan Katambak, Kota Lama volume kendaraan tertinggi yaitu pukul 10.00 WITA sebanyak 563 unit. Responden yang mengalami gangguan komunikasi seperti harus berteriak jika berbicara sebanyak 33.3\%, gangguan fisiologis seperti susah tidur sebanyak $53.3 \%$, gangguan Psikologi seperti mudah marah atau emosi sebanyak $63.3 \%$. Kesimpulan penelitian ialah tingkat kebisingan tertinggi terjadi di Jalan MT. Haryono pada Hari Senin dan telah melebihi baku mutu untuk wilayah perdagangan. Keluhan subjektif yang dirasakan yaitu gangguan psikologi seperti mudah emosi atau marah.
\end{abstract}




\section{JURNAL REGEHATAN LINGKUNGAN

\section{PENDAHULUAN}

Kebisingan adalah bunyi yang tidak diinginkan dari usaha atau kegiatan dalam tingkat dan waktu tertentu yang dapat menimbulkan gangguan kesehatan manusia dan kenyamanan lingkungan(1). Penggunaan kendaraan bermotor yang tinggi telah meningkatkan masalah lingkungan seperti polusi udara dan kebisingan lalu lintas. Paparan terus menerus ke tingkat kebisingan yang tidak dapat diterima dapat menyebabkan masalah lingkungan yang dapat mempengaruhi kualitas hidup penghuni seperti depresi, gangguan tidur, gangguan efisiensi kerja yang buruk dan efek kesehatan yang merugikan. Kebisingan lingkungan merugikan masyarakat $0,2 \%-2,0 \%$ dari produk domestik bruto (2).

Kegiatan transportasi tidak lepas dari adanya kendaraan bermotor. Dewasa ini nilai kepemilikan kendaraan bermotor semakin meningkat, baik kendaraan bermotor milik pribadi maupun yang bukan milik pribadi seperti angkutan umum. Hal tersebut menyebabkan semakin meningkatnya kepadatan arus lalu lintas di jalan raya, dan hal ini sangat erat hubungannya dengan kebisingan, karena kebisingan lalu lintas berasal dari suara yang dihasilkan dari kendaraan bermotor terutama dari mesin kendaraan, knalpot, serta akibat interaksi antara roda dengan jalan (3).

Berdasarkan data World Health Organization (WHO) tahun 2012 yang dikutip dari (Septiana \& Widowati, 2017) terdapat 5,3\% atau 360 juta orang di dunia yang mengalami gangguan pendengaran. Pemerintah Australia pada Januari 2012 menyatakan bahwa 37\% gangguan pendengaran dikarenakan kebisingan yang terlalu tinggi. Menurut World Health Organization (WHO) pada tahun 2012 prevalensi gangguan pendengaran di Asia Tenggara adalah 156 juta orang atau $27 \%$ dari total populasi sedangkan pada orang dewasa di bawah umur 65 tahun adalah 49 juta orang atau 9,3\% yang disebabkan karena suara keras yang dihasilkan di tempat kerja (4).

Laju pertumbuhan transportasi di Indonesia mengalami peningkatan dari tahun ke tahun. Laju pertumbuhan sepeda motor di Indonesia paling tinggi di bandingkan negara ASEAN, yakni $13,2 \%$ dibanding transportasi lainnya. Penyebab meningkatnya laju pertumbuhan sepeda motor adalah sepeda motor merupakan sarana transportasi yang murah dan terjangkau. Untuk laju penjualan mobil pada periode Januari-Juli 2017 sebanyak 618.808 unit atau meningkat 4,17 persen dibandingkan periode yang sama tahun lalu, yakni 594.018 unit. Sektor transportasi memberikan konstribusi yang potensial dalam meningkatnya kebisingan. Semakin meningkatnya jumlah kendaraan maka aktivitas transportasi yang melintasi pada suatu wilayah akan semakin padat dan diiringi dengan meningkatnya kebisingan (5).

Berdasarkan data dari Samsat Kendari bahwa jumlah kendaraan bermotor di Kota Kendari pada tahun 2016 yaitu jumlah sedan, jeep, dan ST wagon sebesar 1.966 unit, jumlah bus dan mick bus sebesar 16.304 unit, jumlah truck dan pickup sebesar 7.359 unit dan jumlah sepeda motor sebesar 65.529 unit. Pada tahun 2017 jumlah sedan, jeep, dan ST wagon sebesar 2.461, jumlah bus dan mick bus sebesar 20.336 unit, jumlah truck dan pickup sebesar 9.171 unit dan jumlah sepeda motor sebesar 83.515 unit. Jumlah kendaraan bermotor di Kota Kendari terus mengalami peningkatan pada tahun 2018 yang dimana jumlah sedan, jeep, dan ST wagon sebesar 1.874, jumlah bus dan mick bus sebesar 20.766 unit, jumlah truck dan pickup sebesar 8.290 unit dan jumlah sepeda motor sebesar 72.480 unit.

Peningkatan jumlah kendaraan bermotor di Kota Kendari 3 tahun terakhir, akibatnya jumlah arus lalu lintas dan jenis kendaraan yang menggunakan ruas-ruas jalan semakin bertambah. Hal ini menimbulkan masalah dibidang transportasi, seperti peningkatan jumlah kecelakaan, masalah polusi udara, dan polusi suara (kebisingan) yang di timbulkan oleh lalu lintas terhadap lingkungan sekitarnya.

Penelitian sebelumnya yang dilakukan oleh Syaifuddin (2019) mengenai tingkat kebisingan transportasi di Kota Padang menunjukan bahwa tingkat kebisingan di Kota Padang sudah maksimum dari batas kebisingan yang ditetapkan oleh pemerintah (sesuai dengan baku Mutu yang ada). Berdasarkan pengamatan di lapangan dan hasil pembahasan, faktor kebisingan yang timbul disebabkan oleh beberapa sumber, yaitu mesin kendaraan, knalpot kendaraan, volume lalu lintas, dan hal lainnya yang terkait dengan transportasi. Jumlah kendaraan yang melewati jalan dalam satu waktu mempengaruhi 


\section{JURNAL LESTELATAN ITGEUNGAN \\ UNIV. HALU OLEO \\ (JRI- URO)}

timbulnya kebisingan. Pada saat jam sibuk volume lalu lintas jalan meningkat sehingga menyebabkan wilayah tersebut mengalami kebisingan lebih tinggi (6).

Kota Kendari merupakan Ibu Kota Provinsi Sulawesi Tenggara yang perkembangannya cukup pesat dengan jumlah penduduk yang begitu banyak serta banyaknya masyarakat yang keluar masuk dari luar kota menggunakan transportasi darat. Akibatnya laju transportasi juga semakin bertambah sehingga tingkat kebisingan yang disebabkan oleh aktivitas transportasi juga semakin meningkat. Kebisingan yang disebabkan oleh aktivitas transportasi juga dapat berakibat pada lingkungan serta mengganggu kenyamanan masyarakat yang tinggal di wilayah tersebut. Kebisingan akibat transportasi merupakan masalah yang cukup banyak terjadi terutama di daerah yang aktivitas sosialnya tinggi seperti di tempat perbelanjaan, perkantoran, pendidikan dan kesehatan. Dampak kebisingan terhadap kesehatan masyarakat seperti gangguan psiokologis (gangguan bekerja, belajar, tidur, kejengkelan, kecemasan, dan lainnya), gangguan pendengaran, dan gangguan komunikasi.

\section{METODE}

Jenis penelitian yang digunakan bersifat deskriptif. Penelitian deskriptif yaitu menggambarkan bagaimana tingkat kebisingan pada lokasi yang diteliti dan menggambarkan keluhan subjektif terhadap orang terpapar di lokasi yang diteliti. Penelitian ini dilakukan pada ruas jalan yang terdapat di tiga lokasi pusat kesibukkan berlangsungnya aktivitas kendaraan yaitu di jalan MT. Haryono, jalan H. Abdullah Silondae, dan di jalan Katambak, Kota Lama. Populasi untuk pengukuran kebisingan dalam penelitian ini adalah di wilayah perdagangan yang ada di Kota Kendari. Sampel dalam pengukuran kebisingan adalah di pasar mandonga, pasar sentral Wua-wua dan pasar sentral Kota.
HASIL

Tingkat Kebisingan

Tabel 1. Tingkat Kebisingan di Jalan MT. Haryono

\begin{tabular}{cccc}
\hline \multirow{2}{*}{$\begin{array}{c}\text { Waktu } \\
\text { Pengukuran }\end{array}$} & \multicolumn{3}{c}{ Tingkat Kebisingan dB(A) } \\
\cline { 2 - 4 } S1 $(07.00)$ & 61,6 & Selasa & Minggu \\
\hline L2 $(10.00)$ & 62,6 & 51,7 & 60,2 \\
\hline L3 $(15.00)$ & 79,5 & 59,4 & 61,5 \\
\hline L4 $(20.00)$ & 61,0 & 61,6 & 63,4 \\
\hline Ls & $\mathbf{7 2 , 5}$ & 63,6 \\
\hline Keterangan & $\begin{array}{c}\text { Melebihi } \\
\text { Baku Mutu } \\
\text { Kebisingan }\end{array}$ & $\begin{array}{c}\text { Tidak } \\
\text { Melebihi } \\
\text { Baku Mutu } \\
\text { Kebisingan }\end{array}$ & $\begin{array}{c}\text { Tidak } \\
\text { Melebihi } \\
\text { Baku Mutu } \\
\text { Kebisingan }\end{array}$ \\
\hline
\end{tabular}

Tabel 1 menunjukkan bahwa tingkat kebisingan siang hari atau Ls di Jalan M.T Haryono, didapatkan nilai bising sebesar 72.5 $\mathrm{dB}(\mathrm{A})$ untuk Hari Senin, 60.5 dB(A) untuk Hari Selasa dan $62.5 \mathrm{~dB}(\mathrm{~A})$ untuk Hari Minggu. Tingkat kebisingan rata-rata/hari paling tinggi terjadi pada Hari Senin yang telah melebihi baku mutu kebisingan untuk wilayah perdagangan yaitu $65 \mathrm{~dB}(\mathrm{~A})$.

Tabel 2. Tingkat Kebisingan Di Jalan $\mathbf{H}$. Abdullah Silondae

\begin{tabular}{|c|c|c|c|}
\hline \multirow{2}{*}{$\begin{array}{c}\text { Waktu } \\
\text { Pengukuran }\end{array}$} & \multicolumn{3}{|c|}{ Tingkat Kebisingan dB(A) } \\
\hline & Senin & Selasa & Minggu \\
\hline L1 (07.00) & 57,3 & 57,5 & 56,5 \\
\hline L2 (10.00) & 56,5 & 54,8 & 53,8 \\
\hline L3 (15.00) & 55,8 & 58,9 & 56,6 \\
\hline L4 (20.00) & 61,7 & 57,1 & 63,9 \\
\hline LS & 58,9 & 57,1 & 60,1 \\
\hline Keterangan & $\begin{array}{c}\text { Tidak } \\
\text { Melebihi } \\
\text { Baku Mutu } \\
\text { Kebisingan }\end{array}$ & $\begin{array}{c}\text { Tidak } \\
\text { Melebihi } \\
\text { Baku Mutu } \\
\text { Kebisingan }\end{array}$ & $\begin{array}{c}\text { Tidak } \\
\text { Melebihi } \\
\text { Baku Mutu } \\
\text { Kebisingan }\end{array}$ \\
\hline
\end{tabular}

Tabel 2 menunjukkan bahwa tingkat kebisingan siang hari atau Ls di Jalan $\mathrm{H}$. Abdullah Silondae, didapatkan nilai bising sebesar 58.9 dB(A) untuk Hari Senin, 57.1 dB(A) untuk Hari Selasa dan $60.1 \mathrm{~dB}(\mathrm{~A})$ untuk Hari Minggu. Tingkat kebisingan paling tinggi terjadi pada Hari Minggu yang belum melebihi baku mutu yang telah ditetapkan untuk wilayah perdagangan yaitu $65 \mathrm{~dB}(\mathrm{~A})$. 


\section{JURNAT LESTELATAN INGEUNGAN \\ UNIV. HALU OLEO \\ (JRI- URO)}

Tabel 3. Tingkat Kebisingan di Jalan Katambak Kota Lama

\begin{tabular}{cccc}
\hline Waktu & \multicolumn{3}{c}{ Tingkat Kebisingan dB(A) } \\
\cline { 2 - 4 } Pengukuran & Senin & Selasa & Minggu \\
\hline L1 $(07.00)$ & 61,0 & 60,2 & 65,0 \\
\hline L2 $(10.00)$ & 68,2 & 60,7 & 61,2 \\
\hline L3 (15.00) & 63,6 & 59,7 & 61,0 \\
\hline L4 (20.00) & 61,6 & 65,5 & 73,6 \\
\hline Ls & 64,9 & 62,6 & 69,2 \\
\hline Keterangan & $\begin{array}{c}\text { Tidak } \\
\text { Melebihi } \\
\text { Baku Mutu } \\
\text { Kebisingan }\end{array}$ & $\begin{array}{c}\text { Tidak } \\
\text { Melebihi } \\
\text { Baku Mutu } \\
\text { Kebisingan }\end{array}$ & $\begin{array}{c}\text { Melebihi } \\
\text { Baku Mutu }\end{array}$ \\
Kebisingan \\
\hline
\end{tabular}

Tabel 3 menunjukkan bahwa tingkat kebisingan siang hari atau Ls di Jalan Katambak, Kota lama, didapatkan nilai bising sebesar 64.9 $\mathrm{dB}(\mathrm{A})$ untuk Hari Senin, $62.6 \mathrm{~dB}(\mathrm{~A})$ untuk Hari Selasa dan 69.2 dB(A) untuk Hari Minggu. Tingkat kebisingan yang paling tinggi terjadi pada Hari Minggu yang telah melebihi baku mutu yang telah ditetapkan untuk wilayah perdagangan sebesar $65 \mathrm{~dB}(\mathrm{~A})$.

\section{Volume Lalu Lintas}

Tabel 4. Volume Lalu Lintas di Jalan MT. Haryono

\begin{tabular}{|c|c|c|c|c|c|}
\hline \multicolumn{2}{|c|}{ Waktu } & \multirow{2}{*}{$\begin{array}{c}\text { LV } \\
\text { (Kendaraan } \\
\text { Berat) }\end{array}$} & \multirow{2}{*}{$\begin{array}{c}\text { HV } \\
\text { (Kendaraan } \\
\text { Ringan) } \\
\end{array}$} & \multirow{2}{*}{$\begin{array}{c}\text { MC } \\
\text { (Sepeda } \\
\text { Motor) }\end{array}$} & \multirow{2}{*}{$\begin{array}{c}\text { Q Total } \\
\text { Kendaraan }\end{array}$} \\
\hline Hari & Jam & & & & \\
\hline \multirow[t]{4}{*}{ Senin } & 07.00 & 3 & 210 & 424 & 637 \\
\hline & 10.00 & 11 & 198 & 527 & 736 \\
\hline & 15.00 & 9 & 287 & 825 & 1121 \\
\hline & 20.00 & 0 & 162 & 527 & 689 \\
\hline \multirow[t]{4}{*}{ Selasa } & 07.00 & 4 & 128 & 380 & 512 \\
\hline & 10.00 & 20 & 175 & 520 & 715 \\
\hline & 15.00 & 15 & 198 & 421 & 634 \\
\hline & 20.00 & 1 & 134 & 470 & 605 \\
\hline \multirow[t]{4}{*}{ Minggu } & 07.00 & 2 & 126 & 346 & 474 \\
\hline & 10.00 & 6 & 171 & 351 & 528 \\
\hline & 15.00 & 13 & 201 & 479 & 693 \\
\hline & 20.00 & 4 & 151 & 385 & 540 \\
\hline
\end{tabular}

Tabel 4 menunjukkan bahwa hasil perhitungan volume lalu lintas tertinggi terjadi pada Hari Senin pukul 15.00 WITA sebanyak 1121 unit dengan rincian kendaraan berat (LV) sebanyak 9 unit, kendaraan ringan (HV) sebanyak 287 unit dan sepeda motor (MC) sebanyak 825 unit. Untuk volume lalu lintas yang terjadi pada Hari Selasa puncak volume lalu lintas yang tinggi yaitu pada pukul 10.00 WITA sebanyak 715 unit dengan rincian kendaraan berat (LV) sebanyak 20 unit, kendaraan ringan (MC) sebanyak 175 unit dan sepeda motor sebanyak 520 unit.
Volume lalu lintas pada Hari Minggu yang tinggi terjadi pada pukul 15.00 WITA sebanyak 693 unit dengan rincian kendaraan berat (LV) sebanyak 13 unit, kendaraan ringan (MC) sebanyak 201 unit dan sepeda motor sebanyak 479 unit.

Tabel 5. Volume Lalu Lintas di Jalan H. Abdullah Silondae

\begin{tabular}{|c|c|c|c|c|c|}
\hline \multicolumn{2}{|c|}{ Waktu } & \multirow{2}{*}{$\begin{array}{c}\text { LV } \\
\text { (Kendaraan } \\
\text { Berat) }\end{array}$} & \multirow{2}{*}{$\begin{array}{c}\text { HV } \\
\text { (Kendaraan } \\
\text { Ringan) } \\
\end{array}$} & \multirow{2}{*}{$\begin{array}{c}\text { MC } \\
\text { (Sepeda } \\
\text { Motor) } \\
\end{array}$} & \multirow{2}{*}{$\begin{array}{c}\text { Q Total } \\
\text { Kendaraan }\end{array}$} \\
\hline Hari & Jam & & & & \\
\hline \multirow[t]{4}{*}{ Senin } & 07.00 & 0 & 77 & 156 & 233 \\
\hline & 10.00 & 1 & 140 & 250 & 391 \\
\hline & 15.00 & 2 & 156 & 237 & 395 \\
\hline & 20.00 & 0 & 62 & 172 & 234 \\
\hline \multirow[t]{4}{*}{ Selasa } & 07.00 & 0 & 88 & 160 & 248 \\
\hline & 10.00 & 0 & 122 & 206 & 328 \\
\hline & 15.00 & 2 & 125 & 215 & 342 \\
\hline & 20.00 & 0 & 78 & 199 & 277 \\
\hline \multirow[t]{4}{*}{ Minggu } & 07.00 & 0 & 64 & 94 & 158 \\
\hline & 10.00 & 1 & 92 & 185 & 278 \\
\hline & 15.00 & 3 & 118 & 316 & 473 \\
\hline & 20.00 & 2 & 174 & 268 & 444 \\
\hline
\end{tabular}

Tabel 5 menunjukkan bahwa hasil perhitungan volume lalu lintas tertinggi terjadi pada Hari Minggu pukul 15.00 WITA sebanyak 473 unit dengan rincian kendaraan berat (LV) sebanyak 3 unit, kendaraan ringan (HV) sebanyak 118 unit dan sepeda motor (MC) sebanyak 316 unit. Volume lalu lintas yang terjadi pada Hari Senin puncak volume lalu lintas yang tinggi yaitu pada pukul 15.00 WITA sebanyak 395 unit dengan rincian kendaraan berat (LV) sebanyak 2 unit, kendaraan ringan (MC) sebanyak 156 unit dan sepeda motor sabanyak 237 unit.

Volume lalu lintas pada Hari Selasa yang tinggi terjadi pada pukul 15.00 WITA sebanyak 342 unit dengan rincian kendaraan berat (LV) sebanyak 2 unit, kendaraan ringan (MC) sebanyak 125 unit dan sepeda motor sebanyak 215 unit. 


\section{JURNAT LESTELATAN ITGEUNGAN \\ UNIV. HALU OLEO \\ (JEL - UE:O)}

Vo1. I/No.3/Bulan Olstober Tahun 2020; e-ISSN: 2723-5203

\begin{tabular}{|c|c|c|c|c|c|}
\hline \multicolumn{2}{|c|}{ Waktu } & \multirow{2}{*}{$\begin{array}{c}\text { LV } \\
\text { (Kendaraan } \\
\text { Berat) }\end{array}$} & \multirow{2}{*}{$\begin{array}{c}\text { HV } \\
\text { (Kendaraan } \\
\text { Ringan) }\end{array}$} & \multirow{2}{*}{$\begin{array}{c}\text { MC } \\
\text { (Sepeda } \\
\text { Motor) } \\
\end{array}$} & \multirow{2}{*}{$\begin{array}{c}\text { Q Total } \\
\text { Kendaraan }\end{array}$} \\
\hline Hari & Jam & & & & \\
\hline \multirow[t]{4}{*}{ Senin } & 07.00 & 8 & 94 & 282 & 384 \\
\hline & 10.00 & 14 & 96 & 243 & 353 \\
\hline & 15.00 & 8 & 85 & 300 & 393 \\
\hline & 20.00 & 1 & 77 & 289 & 367 \\
\hline \multirow[t]{4}{*}{ Selasa } & 07.00 & 9 & 86 & 398 & 493 \\
\hline & 10.00 & 12 & 89 & 348 & 449 \\
\hline & 15.00 & 2 & 74 & 371 & 447 \\
\hline & 20.00 & 5 & 82 & 253 & 340 \\
\hline \multirow[t]{4}{*}{ Minggu } & 07.00 & 4 & 73 & 419 & 496 \\
\hline & 10.00 & 9 & 118 & 436 & 563 \\
\hline & 15.00 & 4 & 85 & 350 & 439 \\
\hline & 20.00 & 2 & 77 & 312 & 391 \\
\hline
\end{tabular}

\begin{tabular}{|c|c|c|}
\hline \multirow{2}{*}{ Gangguan Komunikasi } & \multicolumn{2}{|c|}{ Jumlah } \\
\hline & $\mathbf{n}$ & $\%$ \\
\hline \multicolumn{3}{|c|}{$\begin{array}{l}\text { Mengerti atau paham yang diucapkan } \\
\text { rekan tanpa melihat bibir? }\end{array}$} \\
\hline Ya & 5 & 16,6 \\
\hline Kadang-kadang & 16 & 53,3 \\
\hline Tidak & 9 & 30 \\
\hline Total & 30 & 100 \\
\hline \multicolumn{3}{|l|}{ Pernah ditegur oleh rekan anda? } \\
\hline Pernah & 6 & 20 \\
\hline Kadang-kadang & 20 & 66,6 \\
\hline Tidak pernah & 4 & 13,3 \\
\hline Total & 30 & 100 \\
\hline \multicolumn{3}{|c|}{$\begin{array}{l}\text { Ingin mengurangi bising di tempat } \\
\text { anda? }\end{array}$} \\
\hline Sangat ingin & 3 & 10 \\
\hline Ingin & 20 & 66,6 \\
\hline Tidak ingin & 7 & 23,3 \\
\hline Total & 30 & 100 \\
\hline \multicolumn{3}{|l|}{ Akan meninggalkan area bising? } \\
\hline Sangat ingin & 7 & 23,3 \\
\hline Ingin & 16 & 53,3 \\
\hline Tidak ingin & 7 & 23,3 \\
\hline Total & 30 & 100 \\
\hline
\end{tabular}

Tabel 6 menunjukkan bahwa hasil perhitungan volume lalu lintas tertinggi terjadi pada Hari Minggu pukul 10.00 WITA sebanyak 563 unit dengan rincian kendaraan berat (LV) sebanyak 9 unit, kendaraan ringan (HV) sebanyak 118 unit dan sepeda motor (MC) sebanyak 436 unit.

Volume lalu lintas yang terjadi pada Hari Senin puncak volume lalu lintas yang tinggi yaitu pada pukul 15.00 WITA sebanyak 393 unit dengan rincian kendaraan berat (LV) sebanyak 8 unit, kendaraan ringan (MC) sebanyak 85 unit dan sepeda motor sebanyak 300 unit.

Volume lalu lintas pada Hari Selasa yang tinggi terjadi pada pukul 07.00 WITA sebanyak 493 unit dengan rincian kendaraan berat (LV) sebanyak 9 unit, kendaraan ringan (MC) sebanyak 86 unit dan sepeda motor sebanyak 398 unit.

\section{Keluhan Subjektif}

Tabel 7. Distribusi Responden Berdasarkan Gangguan Komunikasi

\begin{tabular}{lcc}
\hline \multicolumn{2}{c}{ Gangguan Komunikasi } & \multicolumn{2}{c}{ Jumlah } \\
\cline { 2 - 3 } & $\mathbf{n}$ & $\%$ \\
\hline Anda harus berteriak jika sedang & & \\
berbicara? & & \\
Berteriak & 10 & 33,3 \\
Kadang berteriak & 12 & 40 \\
Tidak berteriak & 8 & 26,6 \\
Total & $\mathbf{3 0}$ & $\mathbf{1 0 0}$ \\
\hline Rekan anda harus berteriak jika sedang & & \\
berbicara? & & \\
Berteriak & 7 & 23,3 \\
Kadang berteriak & 17 & 56,6 \\
Tidak berteriak & 7 & 23,3 \\
Total & $\mathbf{3 0}$ & $\mathbf{1 0 0}$ \\
\hline
\end{tabular}

Tabel 7 menunjukkan bahwa dari 30 responden (100\%) terdapat 6 responden (20\%) yang merasa sangat terganggu dalam berkomunikasi, 6 responden (20\%) yang merasa suara bising sangat mengganggu konsentrasi responden, 10 responden (33,3\%) yang berteriak jika sedang berbicara, 7 responden (23.3\%) yang menyatakan bahwa rekannya harus berteriak ketika berbicara dengannya, 5 responden (16.6\%) yang mengerti atau paham yang diucapkan oleh rekannya tanpa harus melihat bibirnya, 6 responden (20\%) yang sering ditegur oleh rekannya karena kurang jelas memahami apa yang dibicarakan, 3 responden (10\%) merasa sangat ingin mengurangi kebisingan, 10 responden (33.3\%) sangat ingin meninggalkan area bising seandainya mereka bisa.

Tabel 8. Distribusi Responden Berdasarkan Gangguan Fisiologis

\begin{tabular}{lcc}
\hline \multirow{2}{*}{ Gangguan Fisiologis } & \multicolumn{2}{c}{ Jumlah } \\
\cline { 2 - 3 } & $\mathbf{n}$ & $\%$ \\
\hline Pusing/sakit kepala & 5 & 16,6 \\
Sering & 16 & 53,3 \\
Kadang-kadang & 9 & 30 \\
Tidak pernah & $\mathbf{3 0}$ & $\mathbf{1 0 0}$ \\
Total & & \\
\hline Mual & 12 & 40 \\
Sering & 13 & 43,3 \\
Kadang-kadang & 5 & 16,6 \\
Tidak pernah & $\mathbf{3 0}$ & $\mathbf{1 0 0}$ \\
Total & \multicolumn{2}{c}{} \\
\hline
\end{tabular}




\section{JURNAL ISESELATAN IINGEUNGAN \\ UNIV. HALU OLEO \\ (JEL - UE:O)}

\begin{tabular}{lcc}
\hline \multirow{2}{*}{ Gangguan Fisiologis } & \multicolumn{2}{c}{ Jumlah } \\
\cline { 2 - 3 } & $\mathbf{n}$ & $\%$ \\
\hline Susah tidur & & \\
Sering & 16 & 53,3 \\
Kadang-kadang & 7 & 23,3 \\
Tidak pernah & 7 & 23,3 \\
Total & $\mathbf{3 0}$ & $\mathbf{1 0 0}$ \\
\hline Cepat lelah & & \\
Sering & 9 & 30 \\
Kadang-kadang & 9 & 30 \\
Tidak pernah & 12 & 40 \\
Total & $\mathbf{3 0}$ & $\mathbf{1 0 0}$ \\
\hline Penegangan & & \\
Sering & 6 & 20 \\
Kadang-kadang & 12 & 40 \\
Tidak pernah & 12 & 40 \\
$\quad$ Total & $\mathbf{3 0}$ & $\mathbf{1 0 0}$ \\
\hline Sakit perut & & \\
Sering & 10 & 33,3 \\
Kadang-kadang & 11 & 36,6 \\
Tidak pernah & 9 & 30 \\
Total & $\mathbf{3 0}$ & $\mathbf{1 0 0}$ \\
\hline
\end{tabular}

Tabel 8 menunjukkan bahwa dari 30 responden (100\%) terdapat 5 responden (16.6\%) yang sering merasa pusing/sakit kepala, 12 responden $(40 \%)$ sering merasa mual, 16 responden $(53,3 \%)$ sering merasa susah tidur, 10 responden (33,3\%) sering merasa sesak napas, 9 responden (30\%) sering merasa cepat lelah, 6 responden (20\%) sering mengalami penegangan otot, 10 responden $(33,3 \%)$ sering mengalami sakit perut.

Tabel 9. Distribusi Responden Berdasarkan Gangguan Psikologi

\begin{tabular}{|c|c|c|}
\hline \multirow{2}{*}{ Gangguan Psikologi } & \multicolumn{2}{|c|}{ Jumlah } \\
\hline & $\mathbf{n}$ & $\%$ \\
\hline \multicolumn{3}{|c|}{$\begin{array}{l}\text { Merasa terganggu atau tidak nyaman } \\
\text { dalam beraktivitas }\end{array}$} \\
\hline Ya & 10 & 33,3 \\
\hline Kadang-kadang & 14 & 46,6 \\
\hline Tidak & 6 & 20 \\
\hline Total & 30 & 100 \\
\hline \multicolumn{3}{|l|}{ Menjadi lebih mudah emosi } \\
\hline Ya & 19 & 63,3 \\
\hline Kadang-kadang & 2 & 6,66 \\
\hline Tidak & 9 & 30 \\
\hline Total & 30 & 100 \\
\hline \multicolumn{3}{|c|}{$\begin{array}{l}\text { Ingin pindah ke tempat yang lebih } \\
\text { tenang }\end{array}$} \\
\hline Ya & 10 & 33,3 \\
\hline Kadang-kadang & 12 & 40 \\
\hline Tidak & 8 & 26,6 \\
\hline Total & 30 & 100 \\
\hline \multicolumn{3}{|c|}{ Berpengaruh terhadap produktivitas } \\
\hline Ya & 16 & 53,3 \\
\hline Kadang-kadang & 4 & 13,3 \\
\hline Tidak & 10 & 33,3 \\
\hline Total & 30 & 100 \\
\hline
\end{tabular}

Tabel 9 menunjukkan bahwa dari 30 responden (100\%) terdapat 10 responden (33.3\%) merasa tidak nyaman dalam beraktivitas dengan suara bising, 10 responden (33.3\%) menjadi mudah emosi atau marah karena suara bising, 19 responden $(63.3 \%)$ ingin pindah ke tempat yang lebih tenang, 16 responden (53.3\%) merasa kondisi bising cukup berpengaruh terhadap produktivitasnya.

\section{PEMBAHASAN}

\section{Gambaran Tingkat Kebisingan Akibat Aktivitas Transportasi}

Kebisingan adalah tingkat bising yang terukur pada jalan yang diteliti dan dilakukan dengan pengukuran secara langsung menggunakan alat Sound Level Meter. Kebisingan lalu lintas jalan merupakan sumber utama yang mengganggu sebagian besar masyarakat perkotaan. Sumber bising lalu lintas antara lain berasal dari kendaraan bermotor, baik roda dua, tiga, maupun roda empat dengan sumber penyebab bising antara lain dari bunyi klakson saat kendaraan ingin medahului atau meminta jalan dan saat lampu lalu lintas tidak berfungsi (7).

Hasil pengukuran kebisingan yang dilakukan menunjukkan bahwa puncak tingkat kebisingan siang hari di jalan MT. Haryono terjadi pada hari senin dimana tingkat kebisingan mencapai $72.5 \mathrm{~dB}(\mathrm{~A})$. Hal tersebut menunjukkan bahwa tingkat kebisingan pada pengukuran tersebut telah melebihi baku mutu yang telah ditetapkan oleh peraturan Keputusan Menteri Lingkungan Hidup No.48 Tahun 1996 yaitu untuk kawasan perdagangan sebesar $65 \mathrm{~dB}(\mathrm{~A})$, Sedangkan berdasarkan Peraturan Menteri Kesehatan RI No. 718/Men/Kes/XI/1987, zona kawasan ini masuk Zona D yang seharusnya diperuntukkan untuk kawasan dengan intensitas kebisingan yang lebih tinggi, seperti pabrik dan stasiun kereta.

Penelitian ini sejalan dengan penelitian yang dilakukan oleh Djalante, (2013) mengenai Simulasi Tingkat Kebisingan Dan Kadar Polutan Sebagai Akibat Aktivitas Transportasi Pada Kawasan Perdagangan Di Kota Kendari (Studi kasus: Kawasan Perdagangan Jalan MT. Haryono Kec. Wua-wua Kota Kendari). Hasil penelitian ini menunjukkan bahwa tingkat kebisingan tertinggi terjadi pada Hari Libur / Sabtu di Segmen 2 (depan Jl.MT.Haryono Lippo 


\section{JURNAL KESERATAN LINGKUNGAN

Plaza) seluas 70,11 dB (A), nilai ini di atas standar kualitas kebisingan disarankan oleh No. KepMenLH. 48 pada tahun 1996, yaitu 70 dB (A). Selain itu, nilainya juga telah melebihi maksimum yang diizinkan untuk perdagangan di wilayah (Zona C) Peraturan menggunakan persamaan yang dikembangkan oleh Menteri Kesehatan No.718 / Men / Kes / XI / 1987 (8).

Penelitian sebelumnya pada tahun 2013 tingkat kebisingan yang tertinggi terjadi pada hari libur. Karena kemungkinan pada tahun 2013 pusat berbelanjaan seperti Lippo Plaza baru dibuka dan ini semakin mendorong antusias masyarakat untuk pergi berbelanja ataupun sekedar jalan-jalan pada hari libur sehingga kondisi lalu lintas pada saat itu semakin banyak dan tingkat kebisingan juga semakin tinggi karena adanya aktivitas masyarakat tersebut. Sedangkan pada penelitian ini tingkat kebisingannya tertinggi terjadi pada hari kerja, hal ini dikarenakan setiap tahun jumlah lalu lintas semakin bertambah sehingga tingkat bising yang dihasilkan oleh lalu lintas juga semakin meningkat dan tingkat kebisingan yang dihasilkan semakin tinggi.

Tingkat kebisingan di Jalan Abdullah Silondae menunjukkan bahwa wilayah ini belum melebihi baku mutu yang telah ditetapkan untuk kawasan perdagangan sebesar $65 \mathrm{~dB}(\mathrm{~A})$ dimana tingkat kebisingan pada wilayah ini mencapai 60.1 dB(A) yang terjadi pada Hari Minggu. Pada jalan $\mathrm{H}$. Abdullah Silondae ini merupakan pusat perdagangan dan aktivitas sosialnya tinggi dan di jalan ini aktivitas kendaraan yang melewati jalan ini juga cukup banyak dan biasa mengalami kemacetan khususnya pada sore hari dan dijalan ini juga banyak terdapat pedagang kaki lima yang berjualan diatas trotoar dan di depan tokotoko. Pada jalan ini banyak kendaraankendaraan yang terparkir di depan toko-toko sampai hampir menghalangi jalan sehingga biasa terjadi kemacetan.

Hasil pengukuran kebisingan yang dilakukan menunjukkan bahwa puncak tingkat kebisingan di jalan Katambak, Kota Lama terjadi pada hari minggu dimana tingkat kebisingan mencapai 69.2 dB(A). Hal ini telah melebihi baku mutu yang ditetapkan oleh peraturan Keputusan Menteri Lingkungan Hidup No.48 Tahun 1996 yaitu sebesar 65 dB(A) untuk kawasan perdagangan. Pada saat pengambilan data kebisingan bahwa semakin banyak transportasi yang lewat maka tingkat kebisingannya juga akan meningkat, dan pada saat penelitian menunjukkan bahwa selain banyaknya kendaraan, kebisingan juga dipengaruhi oleh adanya suara klakson yang dibunyikan oleh kendaraan tersebut dan yang paling berpengaruh yaitu suara klakson yang dihasilkan oleh kendaraan berat seperti kontainer.

\section{Gambaran Volume Lalu Lintas}

Volume lalu lintas adalah jumlah kendaraan yang terhitung pada jalan yang diteliti. Hasil perhitungan volume lalu lintas yang dilakukan di Jalan MT. Haryono pada Hari Senin, Selasa, dan Minggu menunjukkan bahwa rata- rata volume lalu lintas yang tertinggi terjadi pada siang dan sore hari yaitu pukul 10.00 WITA dan 15.00 WITA. Tingginya Volume lalu lintas yang terjadi pada Hari Senin mempengaruhi tingkat kebisingan di jalan MT. Haryono yang dimana tingkat kebisingan Leq selama 10 menit mencapai $79.5 \mathrm{~dB}(\mathrm{~A})$ pada jam 15.00 WITA. Pada Hari Senin yang merupakan hari kantor dan hari sekolah tentunya banyak kendaraan yang melewati jalan ini dan disebabkan oleh tingginya aktivitas masyarakat di jalan MT. Haryono yang dimana pada jam sore banyaknya masyarakat yang pulang dari kantor dan mahasiswa yang pulang dari kampus yang melewati jalan ini dan dijalan ini juga sering terjadi kemacetan dan mayoritas kendaraan yang lewat yaitu sepeda motor.

Pada saat penelitian juga menemukan bahwa di jalan ini selama melakukan penelitian dominan yang melewati jalan ini yaitu sepeda motor dan angkutan umum, selain itu di jalan ini juga terdapat tempat parkirnya kendaraan yang ke luar kota seperti bus dan ini juga menambah jumlah volume lalu lintas yang ada di jalan ini semakin banyak. Dengan banyaknya volume lalu lintas di jalan ini otomatis tingkat kebisingan juga semakin bertambah dan akan mengganggu aktivitas masyarakat di daerah itu khusunya para pedagang kaki lima yang menjual disitu. Selain mengakibatkan kebisingan, dengan volume lalu lintas yang padat di daerah ini bisa juga mengakibatkan kecelakaan yang bisa kapanpun terjadi.

Berdasarkan hasil perhitungan volume lalu lintas di Jalan H. Abdullah Silondae yang dilakukan selama tiga hari yaitu Hari Senin, Selasa dan Minggu menunjukkan bahwa tingkat 


\section{JURNAL REGEHATAN LINGKUNGAN

kebisingan yang tingggi terjadi pada pagi dan sore hari dimana pada Hari Senin dan Minggu volume lalu lintasnya yang tinggi terjadi pada sore hari pukul 15.00 WITA sedangkan pada Hari Selasa volume lalu lintasnya yang tinggi terjadi pada pukul 07.00 WITA. Di jalan ini merupakan wilayah perdagangan yang mana banyak tokotoko maupun pedagang kaki lima yang menjual di sekitaran jalan tersebut. Tingginya volume lalu lintas di jalan ini juga dapat mempengaruhi kebisingan di wilayah ini karena banyaknya kendaraan yang lewat yang mayoritasnya sepeda motor. Pada saat penelitian dilakukan bahwa pada jam-jam sore hari menunjukkan volume kandaraan yang melintas diwilayah ini cukup banyak.

Hasil perhitungan volume lalu lintas di Jalan Katambak, Kota Lama yang dilakukan pada Hari Senin, Selasa, dan Minggu menunjukkan bahwa rata-rata volume lalu lintas tertinggi terjadi pada pagi, siang, dan sore hari. Pada jam sore hari volume lalu lintas yang melewati jalan ini yang dimana banyaknya masyarakat ataupun karyawan yang pulang dari kerja, dan pada sore hari juga pedagangan kaki lima yang berjualan semakin banyak sehingga sebagian masyarakat biasa berbelanja pada sore hari dan ini otomastis akan menambah jumlah kendaraan yang lewat di wilayah tersebut.

\section{Gambaran Keluhan Subjektif}

Gangguan komunikasi ini dapat menyebabkan seseorang harus berbicara kuatkuat untuk berkomunikasi dengan orang lain, bahkan untuk menyatakan sesuatu terkadang diperlukan pengulangan hingga beberapa kali. Berteriak secara terus menerus dapat menyababkan iritasi tenggorokan (9). Berdasarkan hasil pertanyaan dari kuisioner bahwa responden harus berteriak jika sedang berbicara dengan konsumen atau pembeli, hal ini dikarenakan oleh banyaknya kendaraan yang lewat sehingga responden harus berteriak apabila sedang berbicara agar didengar oleh lawan bicaranya atau pembeli.

Gangguan fisiologis adalah gangguan yang pertama timbul akibat bising, fungsi pendengaran secara fisiologis dapat terganggu. Pembicaraan atau instruksi dalam pekerjaan tidak dapat didengar secara jelas, sehingga dapat menimbulkan gangguan lain seperti: kecelakaan. Sebagian responden yang diteliti menyatakan bahwa kebisingan yang disebabkan oleh lalu lintas kendaraan membuat pendengaran responden kurang jelas, mudah pusing/sakit kepala, sering mual, susah tidur, sering sesak napas, cepat lelah, penegangan otot, dan sakit perut (10).

Gangguan psikologis merupakan suatu kesadaran seseorang mengalami gangguan akibat kebisingan yang mempengaruhi kondisi stabilitas mental dan dapat menimbulkan reaksi psikologik. Rincian gejala yang dialami diantaranya adalah perasaan tidak nyaman, kurang konsentrasi, sering bingung dan marah tanpa sebab yang jelas, mudah merasa bosan dan curiga serta mudah jengkel dan tersinggung. Bising dapat menjadi stressor yang mempengaruhi stabilitas mental dan kondisi psikologi, menimbulkan rasa khawatir, jengkel, dan lainnya. Ada berbagai faktor seseorang mengalami gangguan psikologis akibat bising diantaranya kepekaan seseorang terhadap kebisingan, respon individu terhadap sumber bising dan kerentanan individu terhadap kondisi keseimbangan antara emosi dan logika (11).

Hasil penelitian yang ditemukan bahwa responden menyatakan bahwa apabila suara kendaran yang semakin keras akan dirasakan semakin mengganggu pendengaran responden sehingga mengakibatkan responden lebih cepat emosi atau marah. Secara psikologis, kebisingan juga dapat meningkatkan peluang untuk terkena stress. Stress ini akan merujuk pada keadaan cepat marah, sakit kepala dan gangguan tidur. Hal ini dapat disebabkan bising dapat merangsang situasi reseptor vestibular dalam telinga yang akan menimbulkan efek pusing/vertigo, perasaan mual, susah tidur dan sesak napas disebabkan oleh rangsangan bising terhadap sistem saraf.

\section{KESIMPULAN}

1. Berdasarkan penelitian yang telah dilakukan, diperoleh kesimpulan mengenai gambaran tingkat kebisingan bahwa tingkat kebisingan yang paling tinggi terjadi pada lokasi penelitian di Jalan MT. Haryono. Hal ini disebabkan oleh jumlah kendaraan yang melewati jalan ini lebih banyak dan sering terjadi kemacetan yang diperparah oleh banyaknya suara klakson kendaraan bermotor sehingga tingkat kebisingannya semakin meningkat. Dan dari ketiga lokasi tersebut rata-rata tingkat kebisingan tertinggi terjadi pada hari libur. 


\section{JURNAL RESEHATAN LINGKUNGAN

2. Untuk hasil perhitungan volume lalu lintas menunjukkan bahwa puncak volume lalu lintas di Jalan MT. Haryono terjadi pada Hari Senin pukul 15.00 WITA sebesar 1121 unit. Untuk volume lalu lintas di Jalan H. Abdullah Silondae puncak tertinggi terjadi pada Hari Minggu pukul 15.00 WITA sebesar 473 unit. Sedangkan di Jalan Ktambak, Kota Lama puncak volume lalu lintas terjadi pada Hari Minggu pukul 10.00 WITA sebanyak 563 unit. Dari ketiga lokasi tersebut menunjukkan bahwa rata-rata puncak volume lalu lintas terjadi pada sore dan siang hari dan pada hari libur.

3. Untuk keluhan subjektif yang dirasakan oleh responden akibat kebisingan transportasi menunjukkan bahwa yang paling banyak yaitu gangguan psikologi seperti menjadi lebih mudah emosi atau marah sebanyak 19 responden (63.3\%).

\section{SARAN}

1. Dengan tingkat kebisingan yang ditinggi sebaiknya perlu dilakukan upaya-upaya untuk meminimalisir agar kebisingan tersebut tidak melebihi baku mutu kebisingan.

2. Untuk perhitungan volume lalu lintas sebaiknya peneliti selanjutnya menggunakan alat counter untuk lebih memudahkan dalam penelitian. Dengan padatnya volume lalu lintas yang terjadi maka seharusnya perlu diadakan jalur lalu lintas.

3. Dengan adanya keluhan subjektif yang dirasakan oleh masyarakat sebaiknya dilakukan usaha untuk mengurangi kebisingan seperti memasang peredam bising atau menanam tumbuhan yang mampu meredam bising.

\section{DAFTAR PUSTAKA}

1. Menteri Negara Lingkungan Hidup . Surat Keputusan Menteri Negara Lingkungan Hidup Nomor : Kep-48/MENLH/1996/25 November 1996 tentang baku tingkat kebisingan;1996.

2. Suthanaya PA. Modelling Road Traffic Noise For Collector Road (Case Study Of Denpasar City). Procedia Engineering. 2015;125:467-73.

3. Savitri MA, Syafei AD. Pemetaan Tingkat Kebisingan Di Rumah Sakit Islam A. Yani Surabaya. Jurnal Teknik ITS. 2018;7(1):192-5.
4. Septiana NR, Widowati E. Gangguan Pendengaran Akibat Bising. HIGEIA (Journal Of Public Health Research And Development). 2017;1(1):73-82.

5. Satoto HF. Analisis Kebisingan Akibat Aktifitas Transportasi Pada Kawasan Pemukiman Jalan Sutorejo-Mulyorejo Surabaya. Heuristic: Jurnal Teknik Industri. 2018;15(01).

6. Sayfuddin I, Taufan T, Apriyanti LO, Rahayu G, Elnando R, Khairatunnisa M, Et Al. Tingkat Kebisingan Suara Transportasi Di Kota Padang. Jurnal Kapita Selekta Geografi. 2019;2(6):13-8.

7. Khairina K, Arisanty D, Adyatma S. Kebisingan Lalu Lintas Kendaraan Bermotor Pada Ruas Jalan Di Kecamatan Banjarmasin Tengah. Jpg (Jurnal Pendidikan Geografi). 2016;1(1).

8. Djalante S, Nurrakhmad LM, Sugiyarto T. Simulasi Tingkat Kebisingan Dan Kadar Polutan Sebagai Akibat Aktivitas Transportasi Pada Kawasan Perdagangan Di Kota Kendari (Studi Kasus: Kawasan Perdagangan Jalan Mt. Haryono Kec. WuaWua Kota Kendari). MEKTEK. 2013;15(2).

9. Lestari AD, Fihir IM. Hubungan Pajanan Kebisingan Dengan Efek Kesehatan NonAuditory Pada Pekerja Bagian Produksi Di PT. Tokai Dharma Indonesia Pada Tahun 2013; 2013.

10. Malau ND, Manao GRS, Kewa A. Analisa Tingkat Kebisingan Lalulintas Di Jalan Raya. Jurnal Pendidikan, Matematika Dan Sains. 2017;2(1):89-98.

11. Rachmawati IA. Hubungan Antara Intensitas Kebisingan Dengan Keluhan Non Auditory Effect Di Area Turbin Dan Boiler Pembangkit;2015. 